Tropical Journal of Pharmaceutical Research September 2017; 16 (9): 2079-2087

ISSN: 1596-5996 (print); 1596-9827 (electronic)

(C) Pharmacotherapy Group, Faculty of Pharmacy, University of Benin, Benin City, 300001 Nigeria.

All rights reserved.

Available online at http://www.tjpr.org

Original Research Article

http://dx.doi.org/10.4314/tjpr.v16i9.6

\title{
Induction of apoptosis in response to improved gedunin by liposomal nano-encapsulation in human non-small-cell lung cancer ( $\mathrm{NCl}-\mathrm{H} 292)$ cell line
}

\author{
Chukwumaobim Daniel Uzochukwuwulu Nwokwu', Sameera Ranganath \\ Samarakoon $^{1 \star}$, Desiree Nedra Karunaratne ${ }^{2}$, Nuwanthi P Katuvawila ${ }^{3}$, Geethi \\ Kaushalya Pamunuwa ${ }^{2}$, Meran Keshawa Ediriweera ${ }^{1}$ and Kamani Hemamala \\ Tennekoon ${ }^{1}$ \\ ${ }^{1}$ Institute of Biochemistry, Molecular Biology and Biotechnology, University of Colombo, 90, Cumaratunga Munidasa Mawatha, \\ Colombo 03, Sri Lanka, ${ }^{2}$ Department of Chemistry, Faculty of Science, University of Peradeniya, ${ }^{3}$ Sri Lanka Institute of \\ Nanotechnology, Nanotechnology and Science Park, Mahenwatte, Pitipana, Homagama, Sri Lanka
}

*For correspondence: Email: sam@ibmbb.cmb.ac.lk; Tel: +94772988414; Fax: +94112552529

Sent for review: 23 February 2017

Revised accepted: 12 August 2017

\begin{abstract}
Purpose: To investigate the anti-proliferative activity of free and nanoencapsulated gedunin against human non-small-cell lung cancer (NCl-H292) cells.

Methods: Gedunin-loaded nanoliposomes (LG) were prepared using thin-film hydration method. Antiproliferative effects of free and $L D$ were evaluated by sulforhodamine $B$ (SRB) assay. Apoptotic effects of gedunin-loaded liposomes were assessed by evaluating expressions of p53, Bax and survivin genes, caspase 3/7 activities, DNA fragmentation and morphological changes after staining with Hoechst 33342 and acridine orange/ethidium bromide (AO/EB).

Results: Cell proliferation data and microscopic visualization demonstrated a higher anti-proliferative activity for LG than the encapsulant (liposomes) alone. LG exhibited dose- and time-dependent 10-fold anti-proliferative activity compared to the free drug, while displaying tolerable belligerence towards normal human lung fibroblast (MRC-5) cells. Apoptosis detection assays and gene expression analysis revealed the transcriptional modulation of the apoptosis-related genes (p53, survivin and Bax), increased activity of caspase 3/7 and the condensation of nuclear chromatin, implying the induction of apoptosis by the nano-formulation in NCl-H292 cells.

Conclusion: LG may therefore be considered as a potential nano-formulation which can target nonsmall-cell lung cancer.
\end{abstract}

Keywords: Lung cancer, Gedunin, Liposome, Nanoencapsulation, Apoptosis, Anti-proliferative activity, Nuclear chromatin

Tropical Journal of Pharmaceutical Research is indexed by Science Citation Index (SciSearch), Scopus, International Pharmaceutical Abstract, Chemical Abstracts, Embase, Index Copernicus, EBSCO, African Index Medicus, JournalSeek, Journal Citation Reports/Science Edition, Directory of Open Access Journals (DOAJ), African Journal Online, Bioline International, Open-J-Gate and Pharmacy Abstracts

\section{INTRODUCTION}

Lung cancer ranks as the most common cancer among men worldwide and every year approximately 1.35 million lung cancer cases are diagnosed. It ranks as the major cause of cancer deaths among Asian males [1]. Of the two major types (small-cell and non-small-cell) of lung cancer, non-small-cell lung cancer (NSCLC) is the most common type [2]. Though chemotheraphy, radiotheraphy and surgeries are the only available treatment options for lung cancer pateints, chemo and radiotheraphy cause severe side effects. Thus, finding an effective 
chemotherapeutic solution with fewer side effects will improve the prognosis of NSCLC patients.

Plant-derived anti-cancer compounds play a major role in the field of anti-cancer drug discovery and some natural compounds have been approved for clinical use [3]. Although many anti-cancer drugs have been isolated from natural sources, several challenges such as short half-lives, high metabolic instability, low solubility leading to poor absorption and systemic bioavailability are mainly associated with the development of anti-cancer drugs into a globally acceptable level. Further, drug resistance, rapid degradation of the drug, large dosage requirement, and undesirable toxicity are also existing challenges [4]. Research on nanopharmaceuticals has helped overcome these challenges and a number of nano-material-based therapeutic approaches have been used for cancer treatment while some are under clinical development [5]. Lipid-based nano-particles (liposomes) have gained much attention as they possess some unique properties such as conjugation with targeting moieties like antibodies, ease of degradation under specific conditions, and drug-cargo-carrying capacity [6].

Gedunin is one of the major compounds present in the neem tree and it is an Hsp90 inhibitor [7]. Anti-proliferative effects of gedunin have also been reported in several cancer cells such as colon, prostate, ovarian, pancreatic, breast and cervical. However, anti-proliferative effects of gedunin in lung cancer have not been evaluated so far $[7,8]$. Since gedunin is poorly soluble (due to hydrophobic nature) in the aqueous extracellular environment which limits its bioavailability and pharmacokinetic profile, we hypothesize that nano-formulations of gedunin may enhance its anti-proliferative and apoptotic effects in lung cancer cells. Therefore, this study was planned to evaluate anti-proliferative and apoptotic effects of gedunin-loaded liposomal nano-particles in human non-small-cell lung cancer (NCl-H292) cell line.

\section{EXPERIMENTAL}

\section{Materials}

Cell culture medium and reagents were purchased from the American Type Culture Collection (ATCC), Rockville, MD, USA. Caspase-Glo 3 and 7 assay kit was a product of Promega. Egg yolk phosphatidylcholine (approx. $60 \%$, TLC) and cholesterol ( $\geq 99.0 \%$ ), dialysis tubing (12 $000 \mathrm{MWCO}$ ), ethanol, methanol and acetonitrile (HPLC grade) were purchased from Sigma-Aldrich. Gedunin was procured from
Santa Cruz Biotechnology, Texas (sc-203967). Deionized water was filtered through a $0.45 \mu \mathrm{m}$ cellulose nitrate filters (Sartorius Stedim Biotech GmbH 37070, Goettingen, Germany). All other chemicals and reagents used in this study were of analytical grade and purchased from Sigma Aldrich Chemical (St. Louis, MO, USA) unless otherwise indicated.

\section{Cell culture}

$\mathrm{NCl}-\mathrm{H} 292$ (non-samll cell lung cancer) and MRC5 (normal human lung Fibroblast) cell lines were purchased from American Type Culture Collection (ATCC), Rockville, MD, USA. Cell lines were cultured in Dulbecco's Modified Eagle's Medium (DMEM), supplemented with 10 $\%$ fetal bovine serum (FBS), and a $0.1 \%$ antibiotic cocktail (penicillin/streptomycin). Cells were seeded in T-25 flasks, incubated in a humidified atmosphere of $5 \% \mathrm{CO}_{2}$ at $37{ }^{\circ} \mathrm{C}$ to 70 - $80 \%$ confluence and sub-cultured as a monolayer.

\section{Preparation of liposomal nano-formulation}

LG were prepared using the thin-film hydration method originally described [9]. Phosphatidylcholine (100 mg), cholesterol (20 $\mathrm{mg}$ ) and gedunin $(1 \mathrm{mg})$ in $5 \mathrm{~mL}$ ethanol were dissolved in $25 \mathrm{~mL}$ chloroform. Then, a thin film of lipids was prepared after evaporating the organic solvents using a rotary evaporator. The lipid film was allowed to dry overnight at room temperature in a vacuum oven and hydrated with $10 \mathrm{~mL}$ phosphate buffered saline (PBS, pH 7.4) with continuous stirring to incorporate the gedunin. The liposomal suspension was kept overnight at $4-8{ }^{\circ} \mathrm{C}$, to complete hydration. Then, the liposomal suspension was sonicated for $5 \mathrm{~min}$ at $4{ }^{\circ} \mathrm{C}$ in a sonicating bath. It was then dialyzed against PBS (pH 7.4) for 3 days at $4{ }^{\circ} \mathrm{C}$ to purify LG. the Liposome nano-particles were sterilized by autoclaving at $121{ }^{\circ} \mathrm{C}$ for $\sim 15 \mathrm{~min}$,

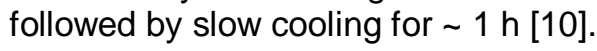

\section{Characterization of LG}

LG $(500 \mu \mathrm{L})$ was dissolved in $10 \mathrm{~mL}$ ethanol and the solution was analyzed by HPLC in a reversed phase C18 column. Deionized water and acetonitrile were used for gradient elution in which the percentage of acetonitrile was increased from 30 to $100 \%$ gradually over a period of $20 \mathrm{~min}$. Next, $100 \%$ acetonitrile was eluted for $5 \mathrm{~min}$. The flow rate used throughout the analysis was $1 \mathrm{~mL} / \mathrm{min}$. The wavelength used for the detection of gedunin was $224 \mathrm{~nm}$ and the retention time was $13.7 \mathrm{~min}$. A series of concentrations of ethanol gedunin solutions was 
used for the construction of the standard curve. These data were used for calculating encapsulation efficiency (EE) and loading capacity (LC). Particle sizes of liposomes were determined using dynamic light scattering technique (zetasizer NanoZS, Malvern Instruments, UK) fitted with a red laser of 633 $\mathrm{nm}$. Liposome suspensions were diluted in PBS and the samples were equilibrated at $25^{\circ} \mathrm{C}$. Then, scattering intensity was measured at an angle of $173^{\circ}$ relative to the incident radiation. Particle size was obtained from size distribution by intensity. Zeta-potential of the same liposomal suspensions described above were measured using Laser Doppler Electrophoresis technique. The values reported are the mean zeta-potential of the liposomal formulations.

\section{Anti-proliferative assays}

$\mathrm{NCl}-\mathrm{H} 292$ and MRC-5 $\left(5 \times 10^{3}\right.$ cells per well) cells were seeded in 96-well tissue culture plates (BD Biosciences, Cowley, UK). The cells were then incubated for $24 \mathrm{~h}$ temperature before treatment with test compounds. After incubation, six serially diluted gedunin concentrations (1.56$50 \mu \mathrm{g} / \mathrm{mL}$ ) and media containing LG (at six serial concentrations ranging from 0.50 to $15 \mu \mathrm{g} / \mathrm{mL}$ ) were tested for anti-proliferative activity by sulphorhodamine B (SRB) assay [11]. Three time intervals (24, 48 and $72 \mathrm{~h}$ ) were used and the standard anticancer drug paclitaxel (at the same doses with LG) was used as the positive control. Prior to the SRB assay, wells were washed with PBS (three times) and fixed in ice-cold $50 \%$ trichloroacetic acid (TCA) at $4{ }^{\circ} \mathrm{C}$ for $1 \mathrm{~h}$. The cells were then stained with $0.4 \%$ SRB dye (prepared in $1 \%$ acetic acid) for $15 \mathrm{~min}$ at room temperature and washed off with $1 \%$ acetic acid, and subsequently solubilized with $10 \mathrm{mM}$ Trisbase in a plate shaker for $1 \mathrm{~h}$ at room temperature. Absorbance was measured at a wavelength of $540 \mathrm{~nm}$ using a microplate reader (Synergy HT, USA). Half-maximal inhibitory concentration $\left(\mathrm{IC}_{50}\right)$ values were determined for tested treatments.

\section{Light microscopy}

Microscopic images of untreated and treated cells were captured using an inverted phasecontrast microscope (Olympus CKX41, Japan) to evaluate the changes in cell morphology following treatments.

\section{Fluorescence microscopy}

Cells cultured on $\left(2 \times 10^{4}\right.$ cells/well) coverslips in 24-well tissue culture plate, were treated with liposomal gedunin $(1,2$ and $4 \mu \mathrm{g} / \mathrm{mL})$ for $24 \mathrm{~h}$.
Following incubation, the wells were washed with PBS and fixed with $4 \%$ formaldehyde $(\mathrm{pH} 7.4)$ at room temperature for $15 \mathrm{~min}$. The cells were washed again with $1 \mathrm{~mL}$ PBS and triple-stained in the dark with three dyes: acridine orange/ethidium bromide and Bis-benzimide (Hoechst 33258) and observed under a fluorescence microscope (Olympus, BX51TRF, Japan).

\section{Caspase $3 / 7$ activity assay}

Caspase $3 / 7$ activity in liposomal gedunin treated $\mathrm{NCl}-\mathrm{H} 292$ cells was measured using CaspaseGlo 3/7 assay kit (Promega) according to manufacturer's protocol.

\section{DNA fragmentation analysis}

$\mathrm{NCl}-\mathrm{H} 292$ cells $\left(1 \times 10^{6}\right.$ cells) were treated with $\mathrm{LG}$ at 1,2 and $4 \mu \mathrm{g} / \mathrm{mL}$ and paclitaxel $(4 \mu \mathrm{g} / \mathrm{mL})$ for $48 \mathrm{~h}$. Cells were collected by trypsinization and centrifugation. Resulting pellets were washed with ice-cold PBS to remove cell debris present. Freshly prepared lysis buffer $(5 \mathrm{~mL})$, containing Tris- $\mathrm{HCl}(5 \mathrm{mM}, \mathrm{pH} 8.0)$, EDTA (5 $\mathrm{mM}, \mathrm{pH} 8.0$ ), $0.5 \%$ SDS, $1 \mathrm{M} \mathrm{NaCl}$, proteinase $\mathrm{K}$ $(0.1 \mathrm{mg} / \mathrm{mL})$, RNase $(0.03 \mathrm{mg} / \mathrm{mL})$ and autoclaved distilled water was added to each sample $(300 \mu \mathrm{L})$ and incubated for $1 \mathrm{~h}$ in a $55^{\circ} \mathrm{C}$ water-bath. DNA was extracted by phase separation method [11]. The DNA pellet was then re-dissolved in $20 \mu \mathrm{L}$ autoclaved distilled water and equal amount of DNA $(1 \mu \mathrm{g})$ was loaded onto the $2 \%$ agarose gel containing ethidium bromide $(0.5 \mu \mathrm{g} / \mathrm{mL})$ and run along with $100 \mathrm{bp}$ ladder at $55 \mathrm{~V}$ for $3 \mathrm{~h}$. The banding pattern was visualized by UV illumination using a Gel-Doc system (Quantum-ST4 1100/20M).

\section{Real-time quantitative PCR of apoptosis- related genes}

The NCl-H292 cells were sub-cultured $\left(2 \times 10^{5}\right.$ cells $/ \mathrm{mL}$ ) in T-25 tissue culture flasks and maintained for $24 \mathrm{~h}$. They were treated with liposomal gedunin ( 0.5 and $1 \mu \mathrm{g} / \mathrm{mL})$ and incubated for another $24 \mathrm{~h}$ along with an untreated control. TRIzol reagent was used to extract RNA. Extracted RNA $(2 \mu \mathrm{g})$ was mixed with $50 \mathrm{ng}$ of random primers and $13.5 \mu \mathrm{L}$ of ultrapure PCR water to make a total volume of $25 \mu \mathrm{L}$ and incubated for $5 \mathrm{~min}$ at $70^{\circ} \mathrm{C}$. CDNA was then synthesized by adding $5 \mu \mathrm{L} 10 \mathrm{mM}$ dNTP mix, $5 \mu \mathrm{L}$ MMLV $5 \mathrm{X}$ reaction buffer, 25 units of RNasin and MMLV RT enzyme (200 units), and the reaction mixture $(25 \mu \mathrm{L})$ was incubated at $37^{\circ} \mathrm{C}$ for $60 \mathrm{~min}$ in a thermal cycler. Stratagene Mx3000P real-time PCR system (Agilent Technologies, CA, USA) was used to 
perform quantitative real-time PCR (qPCR) with the help of MESA Green qPCR MasterMix Plus for SYBR ${ }^{\circledR}$ Assay (Eurogentec, Seraing, Liège, Belgium) with primers previously described [12]. The reaction mixture $(25 \mu \mathrm{L})$ contained $0.5 \mu \mathrm{L}$ of respective forward and reverses primers, $12.5 \mu \mathrm{L}$ SYBR Green MasterMix and water. GAPDH (glyceraldehyde 3-phosphate dehydrogenase) was used as the internal control. The thermal cycle programme was as follows: denaturation at $95{ }^{\circ} \mathrm{C}$ for $10 \mathrm{~min}, 40$ cycles of denaturation at 95 ${ }^{\circ} \mathrm{C}$ for $30 \mathrm{~s}$, annealing at $56{ }^{\circ} \mathrm{C}$ for $1 \mathrm{~min}$, and extension at $72{ }^{\circ} \mathrm{C}$ for $30 \mathrm{~s}$. The relative quantification of each gene expression profile was computed by the $2^{(-\Delta \Delta \mathrm{Ct})}$ method [13].

\section{Statistical analysis}

All data in this study are expressed as mean \pm standard deviation of three independent experiments. GraphPad Prism 6.0.1 software (GraphPad Software Inc., San Diego, CA, USA) was used for statistical analysis and two-way analysis of variance (ANOVA) with Tukey's multiple comparisons test was used to determine significant differences between experimental groups. The differences were considered statistically significant at $p<0.05$.

\section{RESULTS}

\section{Characteristics of liposomal gedunin formulation}

The prepared nanoparticles showed polydispersity index of 0.709 and exhibited characteristics of successful encapsulation, as determined by HPLC. Encapsulation efficiency (EE), loading capacity (LC), particle size distribution and zeta-potential of nanoparticles are presented in Table 1.

\section{Anti-proliferative activity}

The $I C_{50}$ values of the free gedunin, liposomal gedunin, and the standard anticancer drug, paclitaxel for $\mathrm{NCl}-\mathrm{H} 292$ and MRC-5 cells, as well as their safety factors, are displayed in Table 2. Free gedunin showed significant $(p<0.05)$ dosedependent and a time-dependent cytotoxic effect in $\mathrm{NCl}-\mathrm{H} 292$ cells and it was less cytotoxic to MRC-5 cells. Liposomal gedunin also exerted significant $(p<0.05)$ dose-dependent and timedependent cytotoxic effects in $\mathrm{NCl}-\mathrm{H} 292$ cell. However, liposomal gedunin showed higher cytotoxic effects in NCl-H292 cells than to pure gedunin and paclitaxel. Paclitaxel demonstrated higher cytotoxicity in MRC-5 cells than to prepared liposomal gedunin nano-particles.

\section{Cytomorphological changes}

Phase-contrast microscopic images obtained in the presence and absence of treatments, as shown in Figure 1, depict dose-dependent as well as time-dependent characteristic cytomorphological changes: cell shrinkage, cytoplasmic granulation, surface blebbing and blistering and cell lysis were the major visible hallmarks of apoptosis.

\section{Caspases 3 and 7 activities}

According to the results obtained, all three doses $(0.0125,0.0625$ and $1 \mu \mathrm{g} / \mathrm{mL})$ of liposomal gedunin increased the activity of caspase 3 and 7 in a dose-dependent manner, which was only significant $(p=0.03)$ for the highest dose (Fig 2).

Table 1: EE, LC, size and zeta potential of liposome nano-particles

\begin{tabular}{lcccc}
\hline Formulation & $\begin{array}{c}\text { Encapsulation } \\
\text { efficiency (\%) }\end{array}$ & $\begin{array}{c}\text { Loading } \\
\text { capacity (\%) }\end{array}$ & Diameter (nm) & $\begin{array}{c}\text { Zetapotential } \\
(\mathbf{m V})\end{array}$ \\
\hline $\begin{array}{l}\text { Gedunin-loaded } \\
\text { liposomes }\end{array}$ & 86.82 & $7.2 \times 10^{-3}$ & $394.1 \pm 89.4$ & $-54.1 \pm 5.91$ \\
\hline
\end{tabular}

Table 2: $\mathrm{IC}_{50}(\mu \mathrm{g} / \mathrm{mL})$ and safety factors for the test compounds and the standard anticancer drug, Paclitaxel on cancerous and normal lung cell lines at different experimental timelines

\begin{tabular}{|c|c|c|c|c|c|c|}
\hline \multirow[t]{2}{*}{ Formulation } & \multicolumn{3}{|c|}{$\mathrm{NCl}-\mathrm{H} 292$} & \multicolumn{3}{|c|}{ MRC-5 } \\
\hline & $24 h$ & $48 \mathrm{~h}$ & $72 \mathrm{~h}$ & $24 h$ & $48 \mathrm{~h}$ & $72 \mathrm{~h}$ \\
\hline Gedunin & 26.430 & 24.640 & 21.600 & $>50$ & $>50$ & $>50$ \\
\hline Gedunin liposomes & 3.354 & 1.900 & 1.795 & $\begin{array}{c}5.315 \\
(\mathbf{1 . 5 8})^{*}\end{array}$ & $\begin{array}{c}2.937 \\
(1.55)^{*}\end{array}$ & $\begin{array}{l}4.902 \\
(2.73)^{*}\end{array}$ \\
\hline Paclitaxel & 8.372 & 3.286 & 1.596 & $\begin{array}{c}1.518 \\
(\mathbf{0 . 1 8})^{*}\end{array}$ & $\begin{array}{c}0.964 \\
(\mathbf{0 . 2 9})^{*}\end{array}$ & $\begin{array}{c}0.351 \\
(\mathbf{0 . 2 2})^{*}\end{array}$ \\
\hline
\end{tabular}

${ }^{*}$ Bold data in brackets represent the safety factor, i.e. evaluation of the biotoxicity of test compounds on cancerous (NCl-H292) cells relative to normal (MRC-5) cells, determined as the ratio of $I_{50}$ value for MRC-5 cells to that for NCl-H292 cells - the higher the value, the safer the drug. An IC 50 value for liposome (without drug) was not detected within the highest dose tested (100 ppm) 

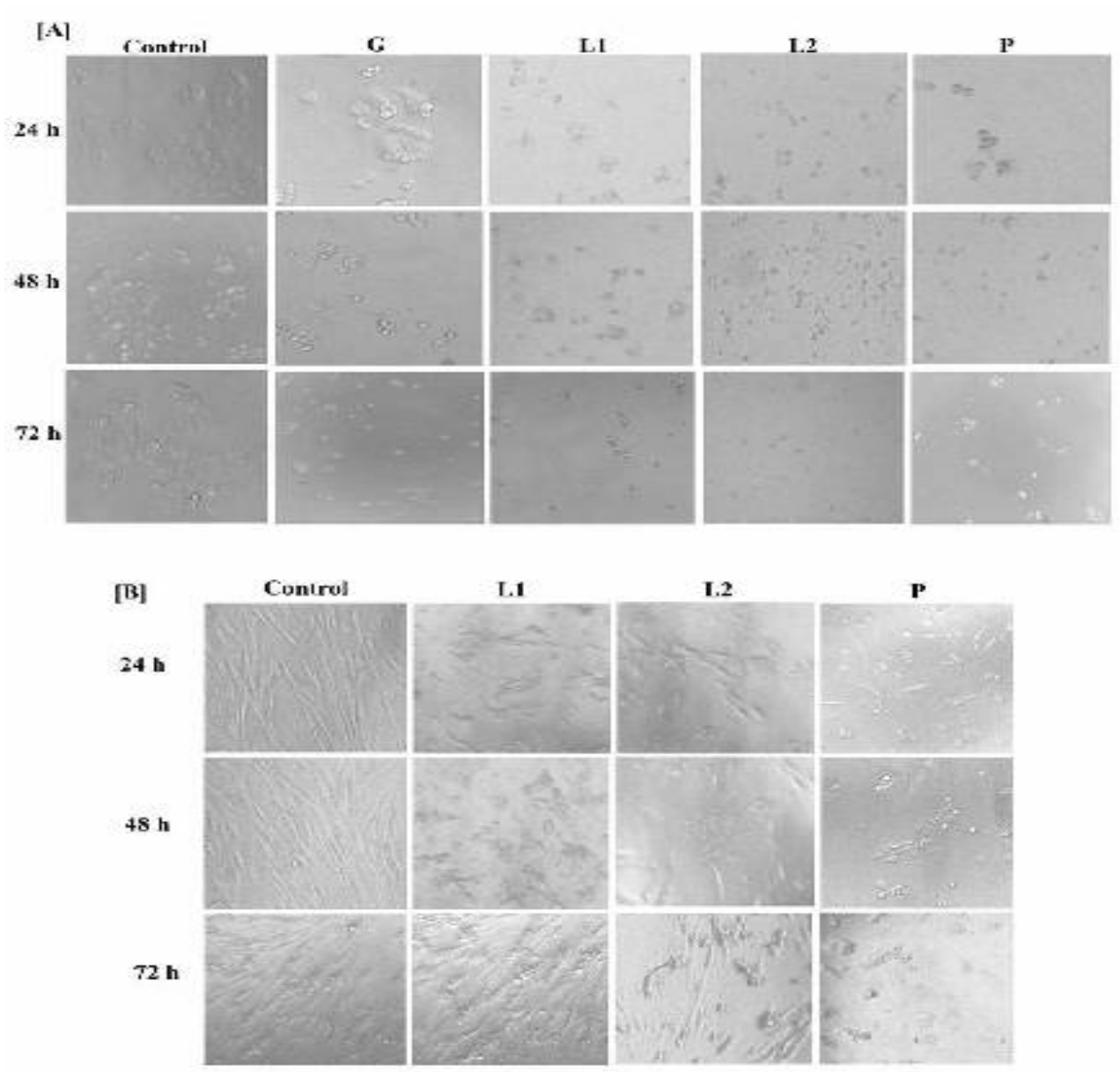

Figure 1: Cytomorphological changes in $[\mathrm{A}] \mathrm{NCl}-\mathrm{H} 292$ and $[\mathrm{B}] \mathrm{MRC}-5$ cells following 24,48 and $72 \mathrm{~h}$ drug treatments, as observed under a phase-contrast light microscope: Across rows: Untreated control; $G=G e d u n i n$ $(25 \mu \mathrm{g} / \mathrm{mL}) ; \mathrm{L} 1$ = Liposomal gedunin $(3.75 \mu \mathrm{g} / \mathrm{mL}) ; \mathrm{L} 2=$ Liposomal gedunin $(15 \mu \mathrm{g} / \mathrm{mL}) ; P=$ Paclitaxel $(3.75$ $\mu \mathrm{g} / \mathrm{mL})$

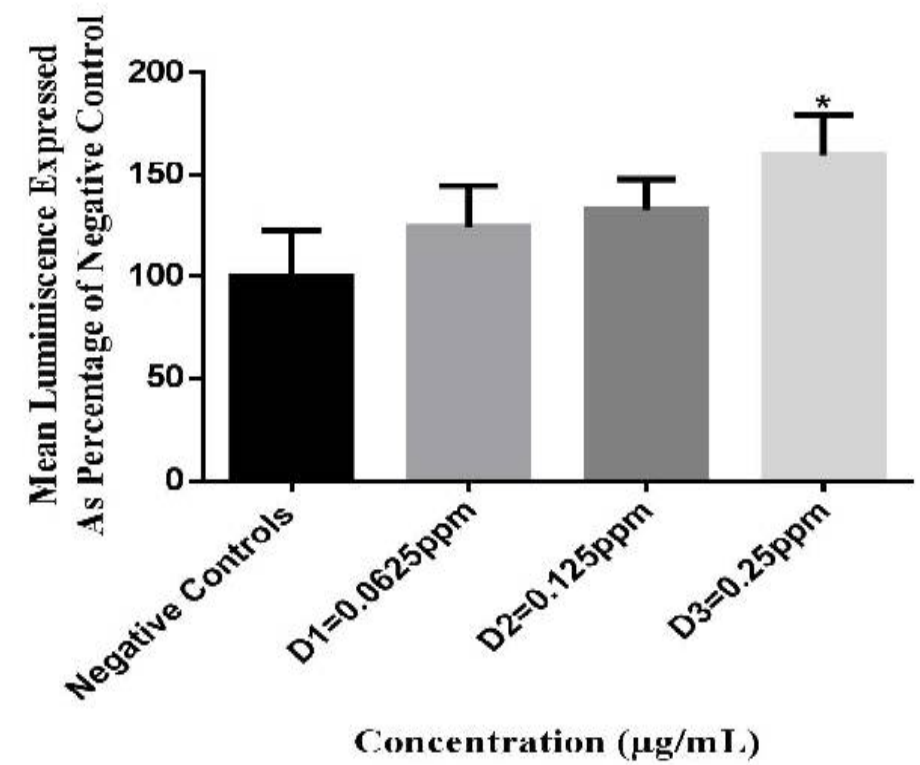

Figure 2: Dose-dependent activation of effector caspases 3 and 7 in untreated and liposomal gedunin--treated $\mathrm{NCl}-\mathrm{H} 292$ cells. Error bars indicate the \pm standard deviation of three replicates. $p=0.03^{*} ; p$ value represents the significance of the difference between the control and the treated groups (two-way ANOVA). $P<0.05$ indicates significant difference among treatments 


\section{DNA fragmentation}

Typical DNA fragmentation was not observed in liposomal gedunin and paclitaxel treated cells. However, a small smearing of DNA was observed at 3 and $4 \mu \mathrm{g} / \mathrm{mL}$ treatments compared to the untreated control (Figure 3).

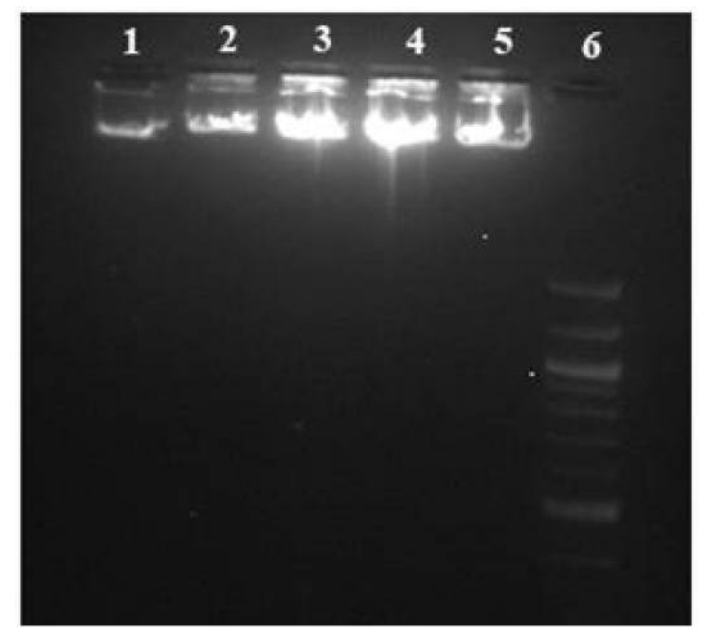

Figure 3: Electropherogram showing induction of high-molecular-weight DNA fragmentation in response to drug exposure: 1 - Untreated control; 2, 3, 4 Liposomal gedunin (1, 2, and $4 \mu \mathrm{g} / \mathrm{mL}) ; 5$ - Paclitaxel $(4 \mu \mathrm{g} / \mathrm{mL}) ; 6$ - 100bp DNA ladder.

\section{Gene expressions of p53, Bax and Survivin}

The data presented in Figure 4 indicate that liposomal gedunin significantly up-regulated the expression of the genes $p 53$ and $\operatorname{Bax}(p<$ 0.0001 ). However, a slight down regulation of the expression of the anti-apoptotic gene, survivin was observed in liposomal gedunin treated cells.

\section{Morphological changes observed under fluorescence microscope}

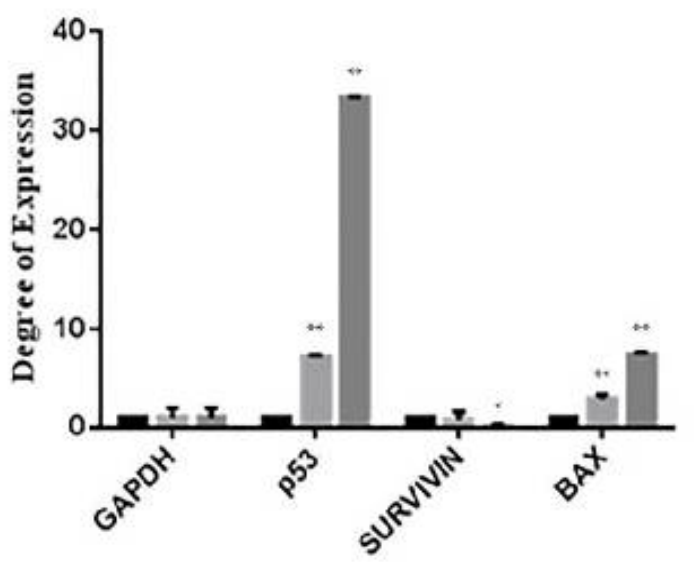

Apoptosis-related Genes

Figure 4: Liposomal gedunin-induced changes in expression of apoptosis-related genes ( $p 53$ and $B a x ;{ }^{* *} p<$ $0.0001)$; Survivin $\left.\left({ }^{*} p>0.05\right)\right]$ after basal normalization with a reference gene $(G A P D H)$; an arbitrary figure of one (1) was allotted to all control samples as a calibrator; $p<0.05$ indicates significant difference among treatments
Morphological changes of the cells treated with liposomal gedunin were observed with the help of a fluorescence microscope after staining with Hoechst 33342 and acridine orange/ethidium bromide (AO/EB) (Figure 5). Viable control cells containing normal nuclei reflected bright green fluorescence, while apoptotic cells that have lost their membrane integrity exhibited different chromophorous (orange to red staining) characteristics (cells stained with $\mathrm{AO} / \mathrm{EB}$ ). Granulations in the nucleus were observed in cells treated with liposomal gedunin, whereas no granulations were observed in untreated controls.

\section{DISCUSSION}

In this study, we have demonstrated the enhanced in vitro anti-cancer activity of improved gedunin by liposomal nano-encapsulation in nonsmall-cell lung cancer (NCl-H292) cell line. When considering anti-proliferative effects of liposomal gedunin and free gedunin, liposomal gedunin showed greater anti-proliferative effects in $\mathrm{NCl}$ H292 cells than to free gedunin. Moreover, liposomal gedunin is less cytotoxic to normal lung fibroblast cells (MRC-5) than the positive control (paclitaxel). Drugs with $\mathrm{IC}_{50}$ values as low as 4 or $10 \mu \mathrm{M}$ have been identified as highly potent cytotoxic agents [14-16]. Thus liposomeencapsulated gedunin fits into this class of anticancer drug leads and may therefore, be considered a potent formulation. Furthermore, liposomal gedunin with comparatively less cytotoxicity to the MRC- 5 cells than the positive control, paclitaxel, highlights the possible use of liposomal gedunin as a more potent drug lead for the treatment of lung cancer.

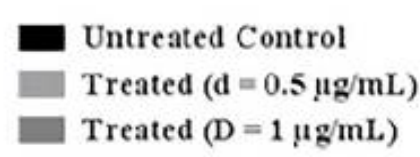



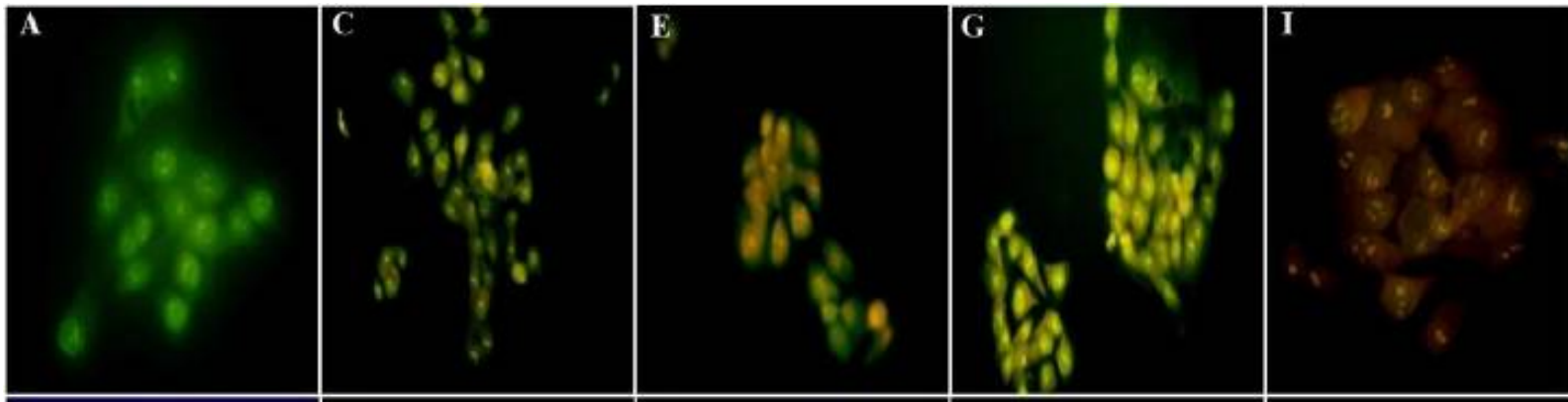

B
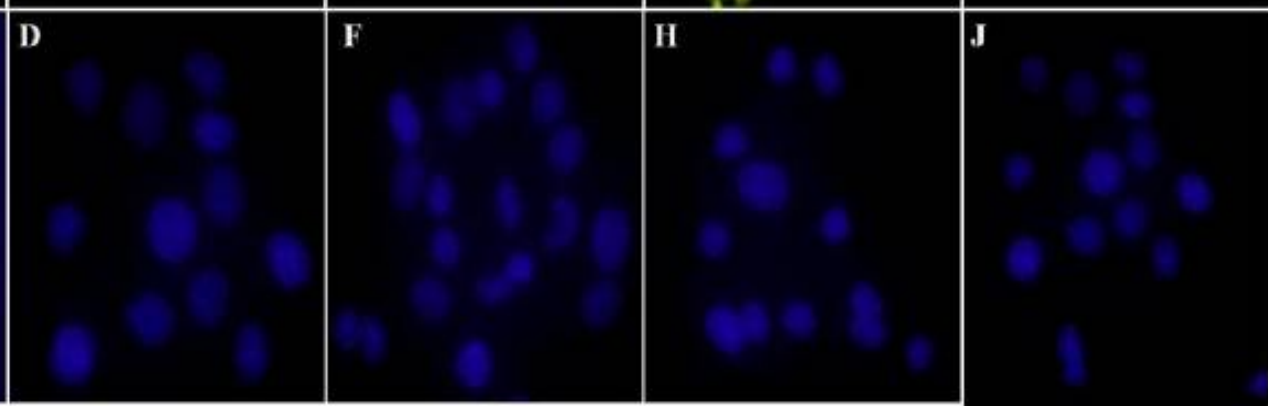

Figure 5: Apoptotic changes in $\mathrm{NCl}-\mathrm{H} 292$ cells following $24 \mathrm{~h}$ drug treatments, as observed under a fluorescence microscope: $A$ = Control $1(\mathrm{AO} / \mathrm{EB}) ; \mathrm{B}=$ Control $2(\mathrm{H}) ; \mathrm{C}=$ Gedunin $(12.5 \mu \mathrm{g} / \mathrm{mL}, \mathrm{AO} / \mathrm{EB}) ; \mathrm{D}=$ Gedunin $(12.5$ $\mu \mathrm{g} / \mathrm{mL}, \mathrm{H}) ; \mathrm{E}=$ Gedunin $(25 \mu \mathrm{g} / \mathrm{mL}, \mathrm{AO} / \mathrm{EB}) ; \mathrm{F}=$ Gedunin $(25 \mu \mathrm{g} / \mathrm{mL}, \mathrm{H}) ; \mathrm{G}=$ Liposomal gedunin $(1 \mu \mathrm{g} / \mathrm{mL}$, AO/EB); $\mathrm{H}=$ Liposome $(1 \mu \mathrm{g} / \mathrm{mL}, \mathrm{H}) ; \mathrm{I}=$ Liposomal gedunin $(4 \mu \mathrm{g} / \mathrm{mL}, \mathrm{AO} / \mathrm{EB}) ; \mathrm{J}=$ Liposomal gedunin $(4 \mu \mathrm{g} / \mathrm{mL}$, H) (Note: AO/EB- stained with acridine orange/ethidium bromide and $\mathrm{H}$-stained with Hoechst 33342)

Apoptosis is important in homeostasis of organs and tissues. Deregulation of apoptosis is one of the hallmark features of cancer [17]. Apoptosis involves activation of proteases, known as caspases (via extrinsic or intrinsic pathway), shrinkage of cells, fragmentation of DNA, chromatin condensation and formation of apoptotic bodies, etc. Genes Bax and p53 play an important role in apoptosis. Bax and p53 are highly expressed in apoptotic cells [17]. Moreover, $p 53$, regulates the anti-apoptotic gene, survivin.

In the present study, apoptosis detection assays and apoptotic related gene expression analysis indicate induction of apoptosis in liposomal gedunin treated $\mathrm{NCl}-\mathrm{H} 292$ cells. The fluorescence microscopic images after $24 \mathrm{~h}$ treatment further indicated that liposomal gedunin caused death of $\mathrm{NCl}-\mathrm{H} 292$ cells mainly by apoptosis. The significant increase of Bax and caspase 3 and 7 activity in liposomal gedunin treated cells suggest the involvement of the intrinsic mitochondrial pathway of apoptosis. It has been reported that Bax induces the release of complex proteins such as cytochrome $\mathrm{C}$, and calcium ions $\left(\mathrm{Ca}^{2+}\right)$, from the mitochondria into the cytosol, activating the intrinsic pathway of p53-mediated apoptosis [18,19]. Significant upregulation (33-fold) of $p 53$ could be linked to an alternative pathway of apoptosis induction or other DNA damage pathways [20].

Induction of apoptosis was not sufficiently reflected by DNA fragmentation pattern obtained in the present study. Certain cells have also been reported to undergo apoptosis without degradation of the nuclear DNA implicitly due to the activities of inhibitor of caspase-activated DNase [21]. DNA fragmentation is a hallmark of late apoptosis which is highly dependent on the inducing agent, endonuclease class and tissuespecificity [21].

The physico-chemical characteristics of nanoparticles hold crucial implications for their capacity as drug delivery vehicles, their fate and toxicity [5-6]. As shown in Table 1 the encapsulation efficiency of liposomes (86.82\%) was as high as those produced by other researchers [22], but the ones used in the present study were of larger size distribution (394 $\mathrm{nm})$, and had an anionic zeta potential (-54) in contrast to their cationic liposomes. Unlike anionic liposomes, cationic liposomes cause induction of cellular stress and change in gene expression [22]. Most of the phosphatidylcholines usually used for liposomal drug delivery have been proven as non-toxic [5,6]. Particle size is instrumental to enhanced permeation and retention (EPR) effect, cellular internalization, sub-cellular trafficking, degradation and clearance. A size range of $\leq 100 \mathrm{~nm}$ is rapidly and efficiently internalized [23]. Although liposomal nano particles prepared in the present study were not in the standard nanoparticle size range, other researchers have been reported an effective chitosan nanoparticles within a size 
range of $150-350 \mathrm{~nm}$ which is almost similar to the size of the nano particles used in the present study [24,25]. This observation underscores the need for implementing metrology standards related to nanoparticle suspensions in order to ensure uniformity and reproducibility. Collectively, the enhanced cytotoxicity of the liposomal formulation is a function of successful gedunin encapsulation and intensified uptake into the cells after treatment, thus validating the quality of the nano-formulation and the preparation method for physical entrapment of drugs.

\section{CONCLUSION}

Enhanced anti-cancer activity of an improved gedunin is achieved by liposomal nanoencapsulation. This is the first documented evidence to demonstrate that nano-encapsulated (liposomal) gedunin enhances anti-proliferative effects against human non-small-cell lung cancer (NCl-H292) cells through p53-initiated, Baxassociated, caspase-dependent activation of apoptosis.

\section{DECLARATIONS}

\section{Acknowledgement}

Financial support provided by Institute of Biochemistry Molecular Biology and Biotechnology, University of Colombo is gratefully acknowledged.

\section{Conflict of Interest}

No conflict of interest associated with this work.

\section{Contribution of Authors}

The authors declare that this work was done by the authors named in this article and all liabilities pertaining to claims relating to the content of this article will be borne by them.

\section{Open Access}

This is an Open Access article that uses a funding model which does not charge readers or their institutions for access and distributed under the terms of the Creative Commons Attribution License (http://creativecommons.org/licenses/by/ 4.0) and the Budapest Open Access Initiative (http://www.budapestopenaccessinitiative.org/rea d), which permit unrestricted use, distribution, and reproduction in any medium, provided the original work is properly credited.

\section{REFERENCES}

1. American Cancer Society. Cancer Facts \& Figures 2008. Atlanta: American Cancer Society; 2008.

2. American cancer society. Lung cancer prevention and early detection, 2014.

3. Bhanot A, Sharma R, Noolvi MN. Natural sources as potential anti-cancer agents: $A$ review. Int $J$ Phytomedicine 2011; 3: 9-26.

4. Anand $P$, Kunnumakkara AB, Newman RA, Aggarwal BB. Bioavailability of curcumin: problems and promises. $\mathrm{Mol}$ Pharm 2007; 4: 807-818.

5. Zhu $Y$, Liao L. Applications of nanoparticles for anticancer drug delivery: a review. J Nanosci Nanotechnol 2015;15: 4753-4773.

6. Gabizon A, Shmeeda H, Barenholz Y. Pharmacokinetics of pegylated liposomal doxorubicin. Clin Pharmacokinet 2003; 42: 419-436.

7. Brandt GE, Schmidt MD, Prisinzano TE, Blagg BS. Gedunin, a novel Hsp90 inhibitor: semisynthesis of derivatives and preliminary structure- activity relationships. J Med Chem 2008; 51: 6495-6502.

8. Boopalan T, Chaudhary A, Murali S, Arumugam A, Lopez $R$, Nandy S, Gutierrez C, Parada J, Agullo $P$, Lakshmanaswamy $R$. Anticancer effect of gedunin against pancreatic cancer cell lines. AACR; Cancer Res 2013; 73(8).

9. Bangham $A D$, Standish MM, Watkins JC. Diffusion of univalent ions across the lamellae of swollen phospholipids. J Mol Biol 1965; 13: 238-IN27.

10. Zuidam NJ, Lee SS, Crommelin DJ. Sterilization of liposomes by heat treatment. Pharm Res 1993; 10: 1591-1596.

11. Samarakoon SR, Thabrew I, Galhena PB, Tennekoon $\mathrm{KH}$. Modulation of apoptosis in human hepatocellular carcinoma (HepG2 cells) by a standardized herbal decoction of Nigella sativa seeds, Hemidesmus indicus roots and Smilax glabra rhizomes with antihepatocarcinogenic effects. BMC Complement Altern Med 2012; 12: 25.

12. Piyathilaka MA, Pathmalal MM, Tennekoon KH, De Silva $B G$, Samarakoon SR, Chanthirika S. Microcystin-LRinduced cytotoxicity and apoptosis in human embryonic kidney and human kidney adenocarcinoma cell lines. Microbiology 2015; 161: 819-828.

13. Livak KJ, Schmittgen TD. Analysis of relative gene expression data using real-time quantitative $P C R$ and the 2- $\triangle \triangle C T$ method. Methods 2001; 25: 402-408.

14. Boik J. Natural compounds in cancer therapy. Oregon Medical Press, Minnestota, USA. 2001

15. Brahemi G, Kona FR, Fiasella A, Buac D, Soukupová J, Brancale A, Burger $A M$, Westwell $A D$. Exploring the structural requirements for inhibition of the ubiquitin E3 ligase breast cancer associated protein 2 (BCA2) as a treatment for breast cancer. J Med Chem 2010; 53: 2757-2765.

16. Kuete V, Fouotsa H, Mbaveng AT, Wiench B, Nkengfack $A E$, Efferth T. Cytotoxicity of a naturally occurring

Trop J Pharm Res, September 2017; 16(9): 2086 
furoquinoline alkaloid and four acridone alkaloids towards multi-factorial drug-resistant cancer cells. Phytomedicine 2015; 22: 946-951.

17. Jiang $X$, Jiang $H$, Shen $Z$, Wang $X$. Activation of mitochondrial protease OMA1 by Bax and Bak promotes cytochrome $c$ release during apoptosis. Proc Natl Acad Sci USA 2014; 111: 14782-14787.

18. Li J, Yuan J. Caspases in apoptosis and beyond. Oncogene 2008; 27: 6194-6206.

19. Youle RJ, Strasser $A$. The BCL-2 protein family: opposing activities that mediate cell death. Nat Rev Mol Cell Biol 2008; 9: 47-59.

20. Koch $M$, Krieger ML, Stölting $D$, Brenner $N$, Beier $M$, Jaehde U, Wiese M, Royer HD, Bendas G. Overcoming chemotherapy resistance of ovarian cancer cells by liposomal cisplatin: molecular mechanisms unveiled by gene expression profiling. Biochem Pharmacol 2013; 85: 1077-1090.

21. Boix J, Llecha N, Yuste VJ, Comella JX. Characterization of the cell death process induced by staurosporine in human neuroblastoma cell lines. Neuropharmacology 1997; 36: 811-821.
22. Lo YL, Lee HP, Tu WC. The use of a liposomal formulation incorporating an antimicrobial peptide from tilapia as a new adjuvant to epirubicin in human squamous cell carcinoma and pluripotent testicular embryonic carcinoma cells. Int J Mol Sci 2015; 16: 22711-22734.

23. Dunne M, Corrigan OI, Ramtoola Z. Influence of particle size and dissolution conditions on the degradation properties of polylactide-co-glycolide particles. Biomaterials 2000; 21: 1659-1668.

24. Son YJ, Jang JS, Cho YW, Chung H, Park RW, Kwon IC, Kim IS, Park JY, Seo SB, Park CR, et al. Biodistribution and anti-tumor efficacy of doxorubicin loaded glycolchitosan nanoaggregates by EPR effect. J Control Release 2003; 91: 135-145.

25. Mohammadpour Dounighi N, Eskandari R, Avadi MR, Zolfagharian H, Mir Mohammad Sadeghi A, Rezayat M. Preparation and in vitro characterization of chitosan nanoparticles containing Mesobuthus eupeus scorpion venom as an antigen delivery system. $J$ Venom Anim Toxins Incl Trop Dis Trop Dis. 2012; 18: 44-52. 